\title{
EFFECT OF DIFFERENT PROTEIN LEVELS ON THE GROWTH AND FEED EFFICIENCY OF SILVER BARB (Barbodes gonionotus) IN FERTILIZED PONDS
}

\author{
Mas Tri Djoko Sunarno
}

\begin{abstract}
This study proposed to establish a suitable protein level in feed formulation for silver barb in a semi-intensive pond. Fingerlings of fish of approximate one-month age were raised in floating cages set in fertilized ponds at a density of 36 fish per cage. Three isocaloric diets with different protein levels $(20,25$ and $30 \%$ ) were given to the fish at ad libitum twice a day for 30 days of the experimental period. The results indicated that an optimal dietary protein level for growth and feed eficiency of silver barb was about $25 \%$. This dietary protein level resulted in low FCR. Therefore, it can be concluded that the diet for fingerlings of silver barb in fertilized ponds should be formulated to contain $25 \%$ protein
\end{abstract}

KEYWORDS: silver barb, tawes, Barbodes gonionotus, protein, pond

\section{INTRODUCTION}

The herbivorous fish species, silver barb or tawes, Barbodes gonionotus, has been cultured semi-intensively in many Asian countries. Various feed ingredients and dietary protein levels were encouraged in Thailand (Sattar, 1987). According to Somsueb (1993), feed for herbivorous species was formulated with $30 \%$ fish meal, $45 \%$ fine rice bran, $24 \%$ peanut meal and $1 \%$ vitamin and mineral premix to contain $30 \%$ protein. In Cambodia, combination of organic fertilizer and supplementary feed of rice bran, corn meal, termites, red ants or aquatic vegetation was applied to silver barb ponds (Nuov \& Nandeesha, 1993). In addition, commercial feed tends to be used in fish culture practices. However, feed in any form contributes the highest cost to total fish production. Reducing feed cost is encouraged. In this case, feed formulation for cultured fish in ponds needs to be determined (Wee, 1989)

In feed formulation, dietary protein for maximum potential growth rate of cultured fish needs to be determined (De Silva, 1989) because this ingredient plays a vital role in fish growth but is expensive. A wide range of dietary protein levels for maximum growth rate of herbivorous fish under laboratory conditions has been observed. Wee and Ngamsnae (1987) recommended about $35 \%$ dietary protein level for silver barb fingerlings. The dietary protein level for other herbivorous species such as Oreochromis aureus (Davis \& Stickney, 1978); O. niloticus (De Silva \& Perera, 1985); and T. Zillii (Mazid et al., 1979) was about 30\%. A study by De Silva \& Gunasekera (1992) showed that different major carps in spite of their varying food habits required dietary protein at a level of
$30 \%$. Inclusion of natural foods affects the composition and amount of diet required by fish (Hepher, 1990; NRC, 1983) since they contain high protein, a material similar to growth promoters, vitamins, and minerals (Viola, 1990). However, there is no information of nutrient requirement for silver barb in ponds. The objective of this experiment, therefore, is to evaluate the effect of dietary protein on the growth and feed utilization of silver barb cultured in a fertilized pond.

\section{MATERIALS AND METHODS}

\section{Feed and Feeding}

Three isocaloric feeds containing different protein levels of 20,25 and $30 \%$ respectively (Table 1) were tested in this experiment. The main source of protein in all feeds was soybean meal. Fish meal, rice bran, cassava starch, corn oil and fish oil were added in diet formulation. Commercial vitamin in this experiment was bought from CP. This mineral premix was adopted from NRC (1983).

Feeds were prepared to cover experimental feed requirements for two weeks. Feed ingredients were analyzed for their proximate composition. In addition, the quality of these feedstuffs was observed by smell, texture and color. Feed ingredients were mixed and thereafter cooked cassava starch was added. The resulting dough was converted into pellets using a Hobart-food mincer. Feeds were then dried. Dried feed was re-analyzed for proximate composition and stored in plastic bags.

Dry matter was determined by drying the sample in an oven at $105^{\circ} \mathrm{C}$ to reach a constant weight. Crude protein was determined using the Kjeldahl method in 
Table 1. Composition (\%) of experimental feed for silver barb used in the experiment

\begin{tabular}{lrrr}
\hline \multirow{2}{*}{ Ingredients } & \multicolumn{3}{c}{ Dietary protein level (\%) } \\
\cline { 2 - 4 } & \multicolumn{2}{c}{$\mathbf{2 0}$} & $\mathbf{3 0}$ \\
\hline Fish meal & 4.5 & 6.0 & 7.5 \\
Soybean meal & 21.0 & 32.0 & 45.1 \\
Rice bran & 53.5 & 41.0 & 29.5 \\
Cassava starch & 15.0 & 15.0 & 11.9 \\
Corn oil & 1.0 & 1.0 & 1.0 \\
Fish oil & 1.0 & 1.0 & 1.0 \\
Vitamin premix $\left(^{*}\right)$ & 2.0 & 2.0 & 2.0 \\
Mineral premix $\left(^{\star *}\right)$ & 2.0 & 2.0 & 2.0 \\
\hline Total & 100.0 & 100.0 & 100.0 \\
\hline Moisture & 10.2 & 9.3 & 9.1 \\
Crude protein & 19.9 & 25.1 & 30.0 \\
Crude fat & 13.5 & 11.4 & 9.0 \\
Ash & 11.8 & 11.8 & 12.3 \\
Gross Energy $(\mathrm{kcal} / \mathrm{g})$ & 4.4 & 4.3 & 4.4 \\
\end{tabular}

Note: $\left({ }^{\star}\right) \mathrm{CP}$ product; $\left({ }^{\star \star}\right)$ adopted from NRC (1983): $7.5 \% \mathrm{MnSO}_{4} \cdot \mathrm{H}_{2} \mathrm{O} ; 3 \%$ $\mathrm{ZnSO}_{4} .7 \mathrm{H}_{2} \mathrm{O} ; 7 \% \mathrm{CuSO}_{4} .5 \mathrm{H}_{2} \mathrm{O} ; 0.6 \% \mathrm{FeSO}_{4} .7 \mathrm{H}_{2} \mathrm{O} ; 5 \% \mathrm{NaCl}_{7} ; .5 \% \mathrm{KIO}_{3}$; $3.5 \% \mathrm{CaHPO}_{4}, 2 \mathrm{H}_{2} \mathrm{O}$. Filler wads added in the formulation to complete $100 \%$

Kjeltec System 1026 Distilling unit (Tecator, 1978) by determining the total nitrogen content. The obtained value was multiplied by a factor 6.25 (AOAC, 1985). Crude lipid was determined using solvent extraction method in Soxtec system HT 1046 Service Unit (Tecator,1978). Crude fiber was determined by acidbased digestion method using a Fibertec system (Tecator, 1978). Ash content was determined by combustion of the sample in a muffle furnace at $550^{\circ} \mathrm{C}$ for 6 hours. Gross energy was estimated using the multification factors $5.65,9.45$, and $4.2 \mathrm{kcal} / \mathrm{g}$ for protein, fat and carbohydrate, respectively.

Experimental feeds were given to the fish ad libitum twice a day (about 09.00 and 17.00) for the 30 day experimental period. In the morning, feed was weighed. In the last feeding, excess feed was reweighed. Feed intake for the day was determined with reducing weighed feed in the morning and reweighed excess feed in the late afternoon. A feeding tray placed in the center of the cage was used to facilitate feed intake

\section{Experimental Habitat and Set-up}

Three earthen ponds of $200 \mathrm{~m}^{2}$ each were used in this experiment. The ponds were dried for a week and limed using $\mathrm{Ca}(\mathrm{OH})_{2}$ at a rate of $625 \mathrm{~kg} / \mathrm{ha}$. Nine net

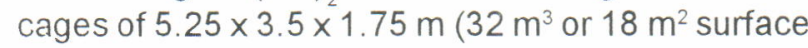
area) each ( $2.5 \mathrm{~cm}$ open mesh size) were suspended in three ponds about $15 \mathrm{~cm}$ above the pond bottom.
Three cages were placed in each pond. The distance between cages was $1 \mathrm{~m}$. Thereafter, canal water was pumped in the ponds to reach $1 \mathrm{~m}$ depth. This water level was maintained during experimental period. Ponds were fertilized using urea containing $45 \%$ nitrogen (N), TSP containing $21 \%$ phosphorous $(P)$ and dry chicken manure containing $1.7 \% \mathrm{~N}$ and $2.8 \% \mathrm{P}$ at a rate of $3.0 \mathrm{~kg} \mathrm{~N}, 1.5 \mathrm{~kg} \mathrm{P}$ and $10 \mathrm{~kg} / \mathrm{ha} / \mathrm{day}$, respectively, every three days.

\section{Experimental Fish}

Silver barb fingerlings of $3-5 \mathrm{~cm}$ were purchased from a hatchery. Fish were nursed in a pond and fed on commercial feed containing $30 \%$ protein ad libitum for about a month to attain fingerling fish size of $8-12 \mathrm{~cm}$. Fish were hand-graded to select relatively equal fish size of about $12 \mathrm{~cm}$ and then acclimatized to experimental conditions for a week. Thereafter, fish were randomly distributed among cages at a rate of 36 fish/cage. At stocking, individual fish length and weight were measured, and samples of fish taken from a batch were sacrificed for proximate analysis of their carcasses. Dead fish during the first week of culture occurred as a result of handling and were replaced with equal fish size. Dead fish was counted daily.

\section{Fish Sampling and Harvest}

Fish sampling was carried out every 10 days. Fish were counted and weighed for biomass. In the same 
time, dissolved oxygen concentration, $\mathrm{pH}$ and water temperature were observed in situ and pond water was sampled using a water column water sampler to observe ammonia- $\mathrm{N}$ and chlorophyll-a. At harvest, individual length and weight of fish were measured and samples of fish taken from each cage were sacrificed for proximate analysis.

\section{Data Analysis}

One-way ANOVA and Least Significant Difference test (LSD) were used to test the statistical significance between treatments for indices of growth, survival, yield, feed and protein intake and utilization. Treatment means are given \pm standard error (SE.) in parentheses. Regression analysis was performed to determine correlation between variables.

\section{RESULTS}

Observed water quality parameters were comparable for all experimental ponds (Table 2). Survival was comparable for all treatments. Dead fish caused by water quality problems were not observed. Reduction in fish number is probably related to handling effects or/and bird predation.

At harvest, mean fish weight ranged from 67 to $81 \mathrm{~g}$. Summary results of the effect of dietary protein levels are presented in Table 3. The relationship be-

Table 2. Water quality parameters of ponds for silver barb fed on different dietary protein levels

\begin{tabular}{lccc}
\hline \multicolumn{1}{c}{ Indices } & Pondl16 & Pondl17 & Pondl18 \\
\hline Dissolved oxygen $(\mathrm{mg} / \mathrm{L})$ & $3.1-8.7$ & $2.9-9.6$ & $2.4-9.7$ \\
Water temperature $\left({ }^{\circ} \mathrm{C}\right)$ & $29.4-32.0$ & $29.4-32.1$ & $29.5-32.1$ \\
$\mathrm{pH}$ & $6.3-8.3$ & $7.0-8.9$ & $6.5-7.8$ \\
$\mathrm{NH}_{3}-\mathrm{N}(\mathrm{mg} / \mathrm{L})$ & $0.21-1.20$ & $0.15-0.81$ & $0.20-0.41$ \\
$\mathrm{TSS}(\mathrm{mg} / \mathrm{L})$ & $8-91$ & $8-81$ & $8-69$ \\
Chlorophyl - $\alpha\left(\mathrm{mg} / \mathrm{m}^{3}\right)$ & $20.6-69.5$ & $15.5-77.2$ & $23.4-64.2$ \\
\hline
\end{tabular}

Table 3. Growth and feed utilization of silver barb fed with different protein levels in fertilized ponds

\begin{tabular}{|c|c|c|c|}
\hline \multirow{2}{*}{ Indices } & \multicolumn{3}{|c|}{ Dietary protein level (\%) } \\
\hline & 20 & 25 & 30 \\
\hline Initial weight (g) & $25.0(1.1)$ & $24.6(0.9)$ & $23.1(0.9)$ \\
\hline Final weight (g) & $67.3(1.2)$ & $79.4(1.4)$ & $81.1(1.0)$ \\
\hline Sunival rate $(\%)$ & $99.1(0.9)^{\mathrm{a}}$ & $97.2(1.6)^{\mathrm{a}}$ & $96.3(0.9)^{\mathrm{a}}$ \\
\hline DWG (g/day) & $1.41(0.07)^{a}$ & $1.83(0.02)^{c}$ & $1.93(0.06)^{c}$ \\
\hline SGR (\%/day) & $3.30(0.20)^{\mathrm{a}}$ & $3.91(0.06)^{b}$ & $4.18(0.16)^{b}$ \\
\hline Net yield $\left(\mathrm{g} / \mathrm{m}^{2} /\right.$ day $)$ & $2.78(0.17)^{a}$ & $3.51(0.07)^{b}$ & $3.66(0.09)^{b}$ \\
\hline Feed intake(g/kgBW/day) & $34.2(2.5)^{b}$ & $28.5(2.1)^{\mathrm{a}}$ & $27.3(1.6)^{a}$ \\
\hline Protein intake (g/kgBW/day) & $6.85(0.49)^{a}$ & $7.12(0.51)^{a}$ & $8.19(0.46)^{b}$ \\
\hline FCR & $1.63(0.25)^{b}$ & $1.28(0.12)^{a}$ & $1.23(0.08)^{a}$ \\
\hline PER & $3.11(0.50)^{\mathrm{a}}$ & $3.13(0.29)^{\mathrm{a}}$ & $2.50(0.55)^{a}$ \\
\hline Carcass protein $(\%)$ at harvest $\left(^{*}\right)$ & $52.2(3.4)^{\mathrm{a}}$ & $54.9(2.7)^{\mathrm{ab}}$ & $54.3(2.5)^{\mathrm{a}}$ \\
\hline Carcass fat $(\%)$ at harvest $\left({ }^{*}\right)$ & $31.3(3.0)^{\mathrm{c}}$ & $31.0(2.7)^{\mathrm{C}}$ & $26.6(1.3)^{\mathrm{b}}$ \\
\hline
\end{tabular}

Note: Values in same row having the same letter are not significantly different; Value in the bracket is SE. (*) Carcass protein and fat of fish at stocking were 61.62 and $18.20 \%$ in dry basis. $S G R=\left(\operatorname{Ln}\left(W_{2}\right)-\operatorname{Ln}\left(W_{1}\right)\right) /\left(T_{2}-T_{1}\right) ; F C R=($ Dry feed intake, $g) /\left(W_{2}(g)-W_{1}(g)\right) ; P E R=$ $\left(W_{2}-W_{1}(g)\right) /($ Protein intake, $g) ; W_{1}^{2}=$ Weight at time $-1 ; W_{2}=$ Weight at time $-2 ; T=$ time 
tween daily weight gain (DWG) and dietary protein levels followed a second order equation: DWG (g/day) $=-3.43+0.37 X-0.006 X^{2}, r^{2}=0.89$. Low growth rate of fish was observed at low protein level. Fish growth increased significantly when fed dietary protein level above $25 \%$. The maximum growth rate was attained at about $29 \%$ protein diet. Specific growth rate (SGR) indices showed a similar trend as DGW indices. Low SGR was achieved by fish fed $20 \%$ dietary protein (3.3\%/day). SGR between 25 and 30\% dietary protein level was comparable (4.0\%/day). Low dietary protein level resulted in low fish yield. High fish yield was observed at $25-30 \%$ dietary protein levels

Fish consuming $20 \%$ dietary protein level at about $34 \mathrm{~g} / \mathrm{kg}$ body weight (BW)/day, higher than the other dietary treatments $(29 \mathrm{~g} / \mathrm{kgBW} / \mathrm{day})$. increase in dietary protein levels positively increased protein intake $(\mathrm{PI})$ as given in the following equation: $\mathrm{Pl}(\mathrm{g} / \mathrm{kgBW} /$ day $)=4.04+0.13 \times, r^{2}=0.64$. Apparent feed conversion ratio (FCR) and protein efficiency ratio (PER) for fish fed 25 and $30 \%$ protein diets were comparable and lowerthan those at $20 \%$ protein diet. Body=pro. tein content was comparable for fish fed various protein levels. Fat content at $20 \%$ and $25 \%$ dietary protein were comparable and lower than that at $30 \%$ protein diet.

\section{DISCUSSION}

Growth of fish is highly related to availability of proper food. When food is insufficient for both maintenance and growth, growth will be inhibited or cease entirely. Under normal condition, silver barb grew at a similar rate with tilapia fingerlings (Milsten et al. 1995). High growth rate of silver barb in the present study may be related to the ability of silver barb to utilize natural food efficiently particularly at young stages (Santos, 1993). Possible high contribution of natural food to overall nutrient requirement in this ex periment can be seen from both low daily feed intake and feed conversion ratio. In contrast, Clark et al. (1990) reported that high growth rate of red tilapia was related to high feeding rate and available microalgae in a pond environment.

This study demonstrates that silver barb require approximately $25 \%$ dietary protein level. This level of protein diet is comparable with common carp (Hepher, 1979), tilapia (Lim, 1989; Clark et al., 1990), and milkfish (Sumagaysay et al, 1991) raised in semi-intensive ponds. However, this finding is lower than those for other fishes observed under laboratory condition for Nile tilapia (Winfrey \& Stickney, 1981; Jauncey, 1982; De Silva \& Perera, 1985), Labeo rohita (Singh et al., 1979), catfish (Chuapoehuk \& Pothisoong, 1985), and silver barb (Wee \& Ngamsnae, 1987 Santos, 1993). According to Jantrarotai \& Lovell
(1991), aquarium studies are more sensitive than pond studies for evaluating nutritional qualities among practical diets, but natural food from the pond can improve productivity of poor quality feeds.

At low dietary protein levels, available protein was not enough to support maximum growth rate. The available protein may be used for energy rather than flesh Wee \& Ngamsnae (1987) stated that the slow growth rate of silver barb at low protein diet is related to the high starch content used in feed formulation. According to Huisman (1976), available metabolic energy in a diet decreased incredibly with increasing daily feed intake because of decreasing feed digestibility by fish (Henken et al., 1986). Excess protein supply was probably observed at the dietary protein level of $30 \%$ as there was a tendency for the growth rate to start to decrease (Zeitun et al., 1976; Jauncey, 1982).

A number of studies showed that the growth rate was positively correlated with the dietary protein requirement in $\mathrm{g} / \mathrm{kgBW} / \mathrm{day}$ (Tacon \& Cowey, 1985). The present study also showed that growth rate of silver barb increased with increasing protein consumption. Daily protein intake during rapid growth of silver barb in the present study was about $7 \mathrm{~g}$ protein $/ \mathrm{kgBW} /$ day. This value was lower than that required for common carp fingerlings to attain their maximum growth (about $12 \mathrm{~g} / \mathrm{kgBW} /$ day) (Kaushik, 1995).

Evaluation of dietary protein level can be viewed from feed and protein utilization. FCR and PER are known to decrease with increasing dietary protein levels (Mazid et al., 1979; Jauncey, 1982; Milsten et al., 1995). The present study indicated that FCR significantly decreased with increasing dietary protein content, similar to a trend observed in silver barb (Wee \& Ngamsnae, 1987) and tilapia (Jauncey, 1982). The best FCR (1.2) was achieved at dietary protein levels above $25 \%$. However, PER in this study was comparable for fish fed various dietary protein levels. This implies that natural food may contribute in supplying some protein. This finding is comparable for tilapia (Mazid et al., 1979; Jauncey, 1982; Milsten et al., 1995). However, PER for silver barb in this study was lower than that observed by Wee \& Ngamsnae (1987).

Fish carcass composition at harvest indicated that there was no difference in the body protein content among fish fed with different dietary protein levels. This finding was similar to the previous studies of silver barb and tilapia showing that body protein content was not greatly affected by changing dietary protein level (Mazid et al., 1979; Winfree \& Stickney, 1981; Jauncey, 1982). However, body fat content was lowest at the highest dietary protein level. Reduction in fat carcass content indicates that diets below 30\% protein level had excess energy. Since this experi- 
ment used isocaloric feed with different protein levels to maintain similar gross energy (about $4.3 \mathrm{Kcal}$ ), the low protein diet contained high carbohydrate (cassava starch) as compared to the higher protein diets. Increase of body fat at lower protein content correlates with high carbohydrate content in supplementary feed (Kaushik, 1995). Zeitler et al. (1983) observed decreasing body fat content in line with increasing dietary protein levels for common carp.

Finally, this study has demonstrated that silver barb cultured in a highly fertilized pond at a rate of 2 fish/ $\mathrm{m}^{2}$ performed best on a diet containing $25 \%$ protein. To further reduce feed cost, the next study should determine vitamin and mineral content in supplementary feed and a maximum standing crop for silver barb in fertilized ponds.

\section{REFERENCES}

AOAC. 1985. Official Methods of Analysis, 12 Ed Association of Official Analytical Chemists. Washington, D.C., New York

Chuapoehuk, W and T. Pothisoong. 1985. Protein requirement of catfish fry, Pangasius sutchi Flower, In: C.Y. Cho C.B. Cowey and T.Watanabe (Eds.) Finfish Nutrition in Asia: Methodology Approaches to Research Development. International Development Research Centre, Ottawa. p: 103--06

Clark, A.E.; W.O. Watanabe; B.L. Olla; and R.I. Wicklund 1990. Growth, feed conversion and protein utilization of Florida red tilapia fed isocaloric diets with different protein levels in seawater pools. Aquaculture, 88: $75--85$

Davis, A.T. and R.R. Stickney. 1978. Growth response of Tilapia aurea to dietary protein quality and quantity. Trans. Am. Fish. Soc., 107: 479--483.

De Silva, S.S. 1989. Reducing feed costs in semi-intensive aquaculture systems in the tropics. Naga, Oct.1989, p: 6--7

De Silva, S.S. and M.K. Perera. 1985. Digestibility of an aquatic macrophyte by the chichlid Etroplus suratenis (Bloch) with observation on the relative merits of three indigenous components as markers and daily changes in protein digestibility. J. Fish Biology, 23 $675--684$

De Silva, S.S. and R.M. Gunasekera. 1992. An evaluation of the growth of Indian and Chinese major carps in relation to the dietary protein content. Aquaculture, 92: $237--241$

Henken, A.M.; M.A.M. Machiels; W. Dekker; and H. Hogendoor. 1986. The effect of dietary protein and energy content on growth and feed utilization of the African catfish, Clarias gariepinus (Buchell, 1822) Aquaculture, 58: 55--74.

Hepher, B. 1979. Supplementary diets and related problems in fish culture. In: J.E. Halver and K. Tiews (Eds.) Finfish Nutrition and Fishfeed Technology, Vol I. Heenaman, Berlin, Germany. p: 343--347.
Hepher, B. 1990. Nutrition of Pond Fishes. Cambridge University Press, New York, U.S.A

Huisman, E.A. 1976. Food conversion efficiencies at maintenance and production levels of carp, Cyprinus carpio L. and rainbow trout, Salmo gairdneri Richardson. Aquaculture, 9: 259--273

Jantraotai, W. and R.T. Lovell. 1991. Evaluation of channel catfish feeds in long-term pond studies and shorth-term aquarium studies. Kasetsart J. Nat. Sci., 25: $463--468$

Jauncey, K. 1982. The effect of varying dietary protein level on the growth, food conversion, protein utilization and body composition of juvenile tilapia (Sarotherodon mossambicus). Aquaculture, 27: 43--54.

Kaushik, S.J. 1995. Nutrient requirements, supply and utilization in the context of carp culture. Aquaculture, 129: $225--241$

Lim, C. 1989. Practical feeding-tilapias. In:: R. T. Lovell (Ed.) Nutrition and Feeding of Fish. AVI Books, Van Nostrand Reinhold, New York, N.Y.

Mazid, M.A., Y. Tanaka, T. Katayama, M. A. Rahman, K.L. Simpson, and C.O. Chichester. 1979. Growth response of Tilapia ziili fingerlings fed isocaloric diets with variable protein levels. Aquaculture, 18: 115-122

Milsten, A., A. Alkon, I. Karplus, M. Kochba, and $Y$. Avnimelech. 1995. Combined effects of fertilization rate, manuring and feed pellet application on fish performance and water quality in polyculture ponds. Aquaculture Research, 26: 55--65.

NRC. 1983. Nutrient Requirements of Warmwater Fishes and Shellfishes. Revised Edition. National Academic Press, Washington, D.C

Nuov, S and M.C. Nandeesha. 1993. Aquafeeds and feeding strategies in Cambodia. In: MB. New, A.G.J. Tacon and I. Csavas (Eds.) Farm-made Aquafeeds. Proceedings of Regional Expert Consultation on Farm-Made Aquafeeds, 14-18 December 1992, Bangkok, Thailand. FAO-AADCP, Bangkok, Thailand. p: $181--200$

Santos, E.V. 1993. Utilization of Selected Terrestrial Vegetation and Aquatic Macrophytes by Herbivorous Fish, Silver barb (Puntius gonionotus). AlT.Diss. no. AE-93-2 c.2, Bangkok Thailand.

Sattar, M.A. 1987. Paragrass as Feed for Herbivorous Carp, Puntius gonionotus. M.Sc. Thesis No. AE 8738. Asian Institute of Technology, Bangkok, Thailand.

Singh, B.N.; V.R.P. Sinha; and D.P. Chakraborty. 1979. Effect of protein quality and temperature on the growth of fingerlings of rohu, Labeo rohita (Hamilton). In J.E. Halver and K. Tiews (Eds.) Finfish Nutrition and Fishfeed Technology, Vol.Il. Heenemaan, Berlin, Germany.

Somsueb, P. 1993. Aquafeeds and feeding strategies in Thailand. In: M.B. New, A.G.J. Tacon and I. Csavas (Eds.) Farm-made aquafeeds. Proceedings of the FAO/AADCP Regional Expert Consultation on FarmMade Aquafeeds, 14-18 December 1992, Bangkok, Thailand. FAO-RAPAAADCP, Bangkok, Thailand. p: 365--385. 
Sumagaysay, N.S., F.E. Marquez, and Y.N. Chiu-Chern. 1991. Evaluation of different supplemental feed for milkfish (Chanos chanos) reared in brackishwater ponds. Aquaculture, 93: 177--189

Tacon, A.G.J. and B.C. Cowey. 1985. Protein and amino acid requirement. In: Tytler, P and P. Calow (Eds.) Fish energetics: New Perspectives. Croom Helm, London. p: 155--183.

Tecator. 1978. Determination of Crude Fibre in Some Feed Samples by Using the Fibertec System and the Weende Method. Application Note 01778

Viola, S. 1990. Non-hormonal promoters for carp:ll feeding trials in pond, Bamidgeh 42(3): 91--94.

Wee, K.L. 1989. Alternate feed sources for finfish in Asia. In: S.S. De Silva (Ed.) Finfish Nutrition Research in Asia. Proceedings of the Second Asian Fish Nutrition Network Meeting, Heinemann Asia, Singapore. p. $25--41$.
Wee, K.L. and P. Ngamsnae. 1987. Dietary protein requirement of fingerlings of the herbivorous carp silver barb, Puntius gonionotus (Bleeker). Aquaculture and Fisheries Management, 18: 121--129.

Winfree, R.A. and R.R. Stickney. 1981. Effect of dietary protein and energy on growth, feed conversion efficiency and body composition of Tilapia aurea. J. Nutrition, 111: 1.001--1.006.

Zeitler, M.H., M. Kirchgessner, and F.J. Scharz. 1983. Effects of dietary protein and energy supplies on carcass composition of carp (Cyprinus carpio). Aquaculture, 36: $37--48$.

Zeitun, I.H., D.E. Ullrey, W.T. Magee, J.L. Gill, and W.G. Bergen. 1976. Quantifying nutrient requirement of fish. J. Fish. Res. Board. Can. 33:167--172. 